УДК 623.444.22

https://doi.org/10.24852/2587-6112.2020.6.354.365

\title{
САБЛЯ МОНГОЛЬСКОГО ВРЕМЕНИ ИЗ МИНУСИНСКОЙ КОТЛОВИНЫ ${ }^{1}$
}

\section{С2020 г. Л. А. Бобров, А. О. Пронин, Ю. А. Филиппович}

Авторами изучена сабля, происходящая из числа случайных находок с территории Минусинской котловины, и, хранящаяся, в настоящее время, в частной коллекции. Сабля снабжена остроугольным (граненым и обоюдоострым на конце) клинком с широким двухсторонним долом и «ладьевидной» гардой удлиненно-ромбической формы. Пята клинка усилена фигурной обоймицей и длинным «язычком». В «хвостовике» были пробиты два отверстия для заклепок, служивших для крепления «щечек» рукояти. Заклепки были снабжены массивными шляпками S-образной формы. На основании типологического анализа авторами установлено, что ближайшие аналоги данной сабли происходят с территории Южной Сибири, Казахстана, Восточной Европы и датируются XIII-XIV вв. Место обнаружения сабли, а также следы окалины на ее поверхности (появление которых, возможно, связано с погребальным обрядом трупосожжения) позволяют предположить, что владельцем сабли был состоятельный воин из числа енисейских кыргызов.

Ключевые слова: археология, монгольские завоевания, енисейские кыргызы, длинноклинковое оружие, сабли Монгольского времени

\section{SABER OF THE MONGOL PERIOD FROM MINUSINSK HOLLOW²}

\section{A. Bobrov, A. O. Pronin, Y. A. Filippovitch}

A saber constituting a random find from the territory of Minusinsk Hollow was studied by the authors. It was found $30 \mathrm{~km}$ from the city of Minusinsk, Krasnoyarsk Oblast, Russian Federation. This saber is currently deposited in a private collection. It is equipped with an acute-angled (faceted and double-edged at the tip) blade with a wide double-sided fuller and an elongated rhombic "scaphoid" guard. The heel of the blade (ricasso) is reinforced with a figured cage and a long "tongue". The saber blade under the cage and "tongue" features a special slot and notches. Two holes for rivets were punched in the "shank", which were used to fasten the "cheeks" of the handle. The rivets were fitted with massive S-shaped heads. Based on the typological analysis, it was established by the authors that the closest counterparts of the saber originate from the territory of Southern Siberia, Kazakhstan and Eastern Europe, and date back to the 13th-14th centuries. The saber discovery site and traces of oxidation on its surface (the formation of which is possibly associated with the burial rite of cremation) suggest that the owner of the saber was a wealthy Yenisei Kyrgyz warrior.

Keywords: archaeology, Mongol conquests, the Yenisei Kyrgyz, long-bladed weapons, sabers of the Mongol period.

Одним из важных направлений современных научных исследований по изучению военно-культурного наследия монгольских и тюркских номадов периода развитого Средневековья является сбор, систематизация и всесторонний анализ длинноклинкового оружия кочевников Евразийской степи времен завоеваний Чингиз-хана и его приемников, а также существования Великой Монгольской империи. В то же время необходимо отметить, что профильная проблематика изучена весьма неравномерно. Так, например, если длинноклинковое оружие воинов Восточной

Европы и Северного Кавказа изучается давно и плодотворно (Белорыбкин, 2001, с. 67-72, 85-92, рис. 83 , 1, 2; Измайлов, 1997, с. 18-34; Горелик, 2002, с. 27, 62-64; Горелик, 2008, с. $161,162,175-178$; Измайлов, 2008, с. 32-39; Горелик, Гредунов, 2014, с. 208-218; Кочкаров, 2008 с. 23-42, 134-144, 148; Rivkin, Isaac, 2017 , p. 74-89; Белорыбкин, Гусынин, Измайлов, 2020 , с. $22-35,110-119)$, то его аналоги с территории Центральной Азии исследованы в значительно меньшей степени. Последний факт затрудняет анализ вооружения населения восточных районов Монгольской

\footnotetext{
Исследование проведено в рамках реализации Государственного задания Министерства науки и высшего образования Российской Федерации в сфере научной деятельности (проект № FSUS-2020-0021).

2 The study was carried out as part of the implementation of the State Assignment of the Ministry of Education and Science of Russia in the field of scientific activity (project No. FSUS-2020-0021)
} 
империи, а также чингизидского военного искусства в целом. Таким образом, введение в научный оборот мечей, палашей и сабель XIII-XIV вв., происходящих с территории Казахстана, Монголии и Южной Сибири, является актуальной научной задачей.

В 2017 г. на территории Минусинской котловины (в 30 км на юго-восток от г. Минусинска, Красноярский край) в ходе проведения сельскохозяйственных работ была обнаружена оригинально оформленная железная сабля, представляющая значительный интерес для отечественных и зарубежных археологов, оружиеведов и военных историков. В 2018 г. она была приобретена частным российским коллекционером и с этого времени хранилась в отечественных оружейных собраниях. В связи с тем, что сабля неоднократно меняла своих владельцев, достоверные сведения о точном месте обнаружения и обстоятельствах находки, к сожалению, были утрачены.

Краткое сообщение о данной сабле (без прорисовок и фотографий) было впервые опубликовано М.А. Обуховой в 2019 г. (Обухова, 2019, с. 79, 80).

Целью настоящей статьи является введение в научный оборот информации о сабле из Минусинской котловины, хранящейся в частной коллекции. Для достижения цели были поставлены следующие задачи: дать подробное описание конструкции рассматриваемой сабли, зафиксировать особенности ее декоративного оформления, уточнить датировку и атрибуцию.

По форме сабельной полосы рассматриваемый образец относится к клинкам со средним изгибом, треугольным (у острия ромбическим) сечением, широким долом и остроугольным обоюдоострым острием (без елмани). Конструктивно сабля состоит из клинка с хвостовиком с заклепкой и железной «ладьевидной» гарды (рис. 1: 1, 2).

Общая длина сабли (от конца хвостовика до острия) - 1020 мм. Общий вес с обоймицей, гардой и заклепкой - 673 г (вес сабельной полосы с обоймицей, без гарды и заклепки - 613 г; вес гарды - 57 г; вес заклепки 3 г). Длина клинка (от верхнего края обоймицы со стороны хвостовика до острия) -

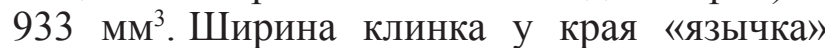
обоймицы/толщина клинка у края обоймицы - 35/6 мм, в центральной части - 34/5 мм, в нижней части (в 10 мм от острия) - 16/2,5

\footnotetext{
При этом длина режущей кромки лезвия -807 мм (см. ниже).
}

мм. Спуски клинка прямые. Плавный изгиб клинка начинается в верхней части сабельной полосы и приобретает максимальную кривизну в ее нижней трети (рис. 1: 1, 2).

Вдоль спинки (обуха) клинка пропущен широкий ярко выраженный двухсторонний дол (длина - 685 мм, ширина - 13 мм) (рис. 1: 3). В нижней части клинка внутренний край дола переходит в ребро жесткости, которое придает острию ромбическое сечение (рис. 1: 4). Эта граненая часть сабельной полосы (длина - 240 мм) имеет двустороннюю заточку. Считается, что подобный усиленный обоюдоострый конец клинка повышал эффективность нанесения колющих ударов сабли (Кочкаров, 2008, с. 28, 40).

Сабельная полоса и другие металлические элементы имеют следы окалины, вызванной длительным пребыванием в среде с высокой температурой (см. ниже). Вероятно, этой же причиной обусловлена незначительная деформация клинка (он поведен в плоскости), a также других конструктивных элементов. На их поверхности фиксируются признаки вздутия и отшелушивания слоев оксидной пленки, неровности и среды коррозии. Тем не менее металл клинка сохранил свою прочность и относительную упругость. При незначительном воздействии на полотно клинка он слегка «пружинит». В целом он не утратил свои характерные геометрические и конструктивные особенности: четко прослеживаются линии дола, обуха, грани на острие, кромки посадочной выемки под обоймицей. Состояние клинка позволяет предположить высокое качество кузнечной работы и мастерство его изготовителя. Основные следы механических повреждений представлены выщербинами (выбоинами и сколами) на участках близ кончика острия (со стороны лезвия), на участке острия близ дола (как со стороны лезвия, так и со стороны обуха), в средней части со стороны лезвия (рис. 1: 3, 4). Самый кончик сабельного острия (около 5-7 мм) обломан (рис. 1:4).

Пята (Ricasso) клинка снабжена массивной железной обоймицей (ширина - 34 мм) с ярко выраженным «язычком» (рис. 2: 1, 2). Общая длина/высота обоймицы с «язычком» со стороны лезвия - 128 мм, ширина язычка - 9 мм. Длина/высота обоймицы со стороны обуха - 41 мм; максимальная толщина обоймицы со стороны обуха близ хвостовика - 11 мм. Нижний край обоймицы украшен прорезью и фигурными полукруглыми вырезами. 
В совокупности они формируют характерный узор в виде фигурной скобки - \{. Верхняя часть «язычка» (с обеих сторон клинка) оформлена остроугольным фестоном-зубчиком (рис. 2: 2).

Кончик «язычка» слегка деформирован и отошел от тела клинка, открыв край специальной выемки на нем (рис. 2: 3). Это позволяет зафиксировать некоторые интересные особенности конструкции оружия, которые обычно ускользают от внимания исследователей. Так, в частности, установлено, что режущая кромка лезвия клинка начинается не от плечиков клинка (как можно было бы предположить), а только от выемки под «язычком». Непосредственно под обоймицей и «язычком» режущая кромка отсутствует. Таким образом, режущая поверхность лезвия составляет 807 мм (то есть $86,5 \%$ от общей длины клинка в 933 мм).

Вторая выемка на теле клинка прослеживается со стороны обуха, к ней плотно примыкает фигурный край железной обоймицы. Проведенный осмотр оружия позволяет сделать вывод, что при сборке сабельной полосы обоймица (предположительно в нагретом состоянии) плотно насаживалась на специально подготовленный для нее участок на основании клинка, вплоть до совпадения краев «язычка» (со стороны лезвия) и обоймицы (со стороны обуха) с краями выемки на теле клинка. При этом долы не заходили под обоймицу (рис. 2: 2).

По всей видимости, функциональное назначение обоймицы с «язычком» было весьма разнообразным. Так, например, она предотвращала повреждение устья ножен об острый край лезвия сабли, обеспечивала «...плотное, без разбалтывания, пребывание клинка в ножнах» (Горелик, 2004, с. 86) а также усиливала пяту клинка. Кроме того, сабля с обоймицей и «язычком» на клинке позволяла применять особый хват оружия, при котором указательный палец воина помещался поверх стержня гарды (Горелик, 2004, с. 86).

Узкий хвостовик удлиненно-трапециевидной формы, венчающий клинок рассматриваемой сабли, незначительно отогнут в сторону лезвия (рис. $2: 1 ; 3: 1,2$ ). Основание хвостовика скрыто краем обоймицы, что не позволяет установить его подлинные размеры. Общая длина видимого участка хвостовика от края обоймицы до верхнего края хвостовика -87 мм, ширина: 18 (в нижней части) - 5 (в верхней части) мм, толщина: 4,5-2 мм. В плоскости хвостовика пробито два сквозных отверстия округлой формы (диаметр - 4 мм). В нижнем из них сохранилась заклепка, служившая для крепления «щечек» сабельной рукояти (рис. 3: $1,2)$. Заклепка состоит из штифта (длина - 20 мм) и массивной S-образной шляпки (длина 14 мм; ширина - 6 мм). Последняя выполнена в виде двух соединенных полумесяцев (рис. 3 : $5)$.

По материалу изготовления сабельная гарда может быть отнесена к классу железных (стальных), на основании особенностей конструкции - к типу «ладьевидных» (подтипу - удлиненно-ромбических). По центру ее «лицевой» стороны пропущено ярко выраженное вертикальное ребро жесткости, выполненное в виде уплощенного валика (рис. $2: 4-7 ; 3$ ) Длина гарды - 120 мм, высота (по бортику) в центральной части - около 21 мм, на концах 2 мм, ширина гарды в центральной части - 24 мм, на концах: 7,5-8 мм.

Гарды подобной конструкции именуются в советской и российской историографии «ладьевидными», так как визуально напоминают раннесредневековое судно с невысокими бортами (Худяков, 1980, с. 36). Последние были образованы глубокими овальными выемками в верхней и нижней части гарды (рис. 2: 4, 5), которые, вероятно, предназначались для дополнительной фиксации щечек рукояти и более глубокого погружения сабли в ножны соответственно. Гарда служила упором для кисти и одновременно защищала ее от рубящих ударов оружия противника (рис. 3: 3, 4).

Металлическое навершие (если оно имелось у данного образца длинноклинкового оружия), верхняя заклепка рукояти, а также прибор ножен до нашего времени не дошли.

Рассматриваемая сабля может быть датирована и атрибутирована на основании типологического анализа.

Сабли с остроугольным (обоюдоострым на конце) клинком, снабженные широкими долами, массивной обоймицей с длинным ярко выраженным «язычком» и удлиненно-ромбической гардой «ладьевидной» формы, в целом не характерны для длинноклинкового оружия народов Центральной Азии и Южной Сибири эпохи Древности, раннего и позднего Средневековья, а также Нового времени (Худяков, 1986; Горбунов, 2006, с. 195, 203; Бобров, Худяков, 2008, с. 274-283; Бобров, Пронин, 2012). Однако они достаточно широко представлены среди материалов, датированных развитым Средневековьем. 
Ключевую роль для датировки и атрибуции сабли играет конструкция и форма клинка, гарды и особенно фигурной обоймицы с «язычком».

М.В. Горелик, изучивший особенности конструкции и системы оформления сабель населения Восточной Европы, Северного Кавказа, Сибири, Центральной и Восточной Азии, пришел к выводу, что обоймы с «язычками» впервые появились в Центральной Азии и к IX в. были заимствованы хазарами. После падения Хазарского каганата указанный конструктивный элемент, по данным М.В. Горелика, достаточно быстро исчезает из ассортимента клинкового оружия западной части Евразии ${ }^{4}$. Повторное его появление и распространение на саблях и палашах региона было связано с монгольским завоеванием XIII в. При этом, в Южной Сибири, а также в континентальной Восточной Азии традиция изготовления обоймиц с «язычками» непрерывалась. Так, в частности, они присутствуют на длинноклинковом оружии воинов династий Сун, Цзинь, а также саблях и палашах кочевников Южной Сибири (Худяков, 1980, с. 35, табл. IV, рис. 1, 6, с. 37, табл. V, рис. 2, с. 38, табл. VI, рис. 1,2 , с. 41, табл. VII, рис. 1, 3, с. 43, табл. VIII, с. 1, 3; Худяков, 1997, с. 16, 17, 22, 23; Горелик, 2002, с. 63, 64; Соловьев, 2003. С. 166 , рис. 18; Ширин, 2003, с. 131, 132, 133, рис. 2, 6; Горелик, 2004; Горелик, 2008, с. 161; Горбунов, 2006, с. 195 , рис. 50, 6, с. 203, рис. 58, 4; Мясников, Ярославцева, 2017, с. 62-65). Весьма вероятно, что сабли со слабо- и среднеизогнутым клинком с массивными (в том числе фигурными) обоймицами и «язычками», удлиненно-ромбическими «ладьевидными» гардами сформировались на территории Южной Сибири и Центральной Азии еще до Монгольской эпохи. Однако их распростране-

4 Американскими исследователями К. Ривкиным и Б. Исааком были опубликованы сабли из частных коллекций, происходящих с территории Восточной Европы и датированных периодом развитого Средневековья. Некоторые из них снабжены обоймицами с «язычками» (Rivkin, Isaac, 2017, p. 60, fig. 26 d, e, 67-69, 80, 82, 84). Однако в большинстве случаев, данные образцы вооружения происходят из числа случайных находок или из разрушенных археологических памятников, что вынудило исследователей датировать их достаточно широко в пределах конца X-XII вв., или концом XII-XIII вв. (Там же). Таким образом, указанные сабли могли быть изготовлены в период Хазарского каганата (а т.же вскоре после его крушения), или Монгольской империи, что не противоречит описанной выше версии М. В. Горелика. ние по Евразии в XIII-XIV вв. в значительной степени связано именно с Чингизидской военной экспансией (рис. $4 ; 5)^{5}$.

Еще одним аргументом в пользу датировки сабли Монгольским временем, является наличие на обоймице и «язычках» полукруглых вырезов и остроугольных зубчиков. Подобное декоративное оформление было весьма характерно именно для длинноклинкового оружия народов Великой степи и сопредельных территорий XIII-XIV вв. (Горелик, 2004, с. 98, рис. 3, 1, 3; The Arts ..., 2008, p. 38, 39; Мясников, Ярославцева, 2017, с. 62-65; Rivkin, 2017, p. $74,76,77,84,86)$. Сочетание в одном образце оружия клинка с широким двухсторонним долом и обоюдоострым острием, удлиненно-ромбической гарды, вырезной обоймицы с длинным «язычком», а также заклепок щечек рукояти с массивными фигурными (в том числе и S-образными шляпками), также встречается на саблях Монгольского времени происходящих с территории Южной Сибири, Восточного Дашт-и-Кипчак и Восточной Европы (Скобелев, Рюмшин, 2010, с. 145, 146, рис. 1; Горелик, Гредунов, 2014, с. 213, 217, рис. 7; Бобров и др., 2020, с. 249, 250).

Ближайшие аналоги рассматриваемого образца длинноклинкового оружия происходят с территории Центральной Украины (Горелик, Гредунов, 2014, с. 217, рис 7), Восточного Казахстана (Бобров и др., 2020, с. 249, 250), южных районов Красноярского края и Хакассии (Скобелев, Рюмшин, 2010, с. 146, рис. 1, с. 148 , рис. 3). Отличительными особенностями сабель серии являются остроугольный слабо- или среднеизогнутый (обоюдоострый у острия) клинок с широкой фигурной обоймицей с «язычком» на пяте, сочетающийся с наклонным хвостовиком с двумя отверстиями для заклепок, а также удлиненно-ромбической «ладьевидной» гардой (рис. 4). Частым элементом оформления такого оружия являются широкие долы вдоль спинки клинка, a также характерные вырезы и зубчики по

Характерно в данной связи, что сабли с удлиненно-ромбическими гардами и широкими обоймицами с длинными «язычками» подтреугольной формы были обнаружены на Золоторевском городище в верховьях p. Суры разрушенном монгольскими войсками в 1237 г. (Белорыбкин, 2001, с. 67-72, 85-92, рис. $83,1,2)$. По всей видимости, центральноазиатское оружие рассматриваемого образца оказало известное влияние и на мастеров Северного Кавказа, продукция которых, получила широкое распространение на территории Улуса Джучи (Горелик, 2008, с. 161, 162, 175-178; Горелик, Гредунов, 2014, с. 212, 213, 216, 217). 
краю обоймиц и «язычков» на пяте сабельной полосы (рис. 5, 2,4,5). Все сабли с подобными признаками уверенно датируются XIII-XIV вв. и соотносятся с комплексом вооружения воинов Чингизидских государств данного периода (Скобелев, Рюмшин, 2010, с. 145,146 , рис. 1 ; Горелик, Гредунов, 2014, с. 213, 217, рис 7; Rivkin, Isaac, 2017, p. 876, 77, 4, fig. 84; p. 86).

Интересно, что весьма схожие образцы вооружения происходят из разных регионов Евразии - от Украины до Ирана и Минусинской котловины (рис. 1; 4; 5). Это, вероятно обусловлено взаимопроникновением оружейных традиций и интенсивным товарообменом среди населения Монгольской империи и ее политических наследников (Скобелев, Рюмшин, 2010, с. 145, 146, рис. 1; Горелик,
Гредунов, 2014, с. 213, 217, рис 7; Бобров и др., 2020, с. 249, 250 $)^{6}$.

Развитая гарда, клинок с широким ярко выраженным двухсторонним долом и массивной фигурной обоймицей с «язычком» свидетельствуют в пользу того, что рассматриваемая сабля может быть датирована серединой XIII - XIV вв. Однако, необходимо учитывать, что, будучи высококачественным образцом длинноклинкового оружия, она могла использоваться на протяжении длительного исторического периода. Факт ее местонахождения на территории Минусинской котловины, а также следы окалины (возможно связанной с погребальным обрядом трупосожжения) свидетельствуют в пользу того, что владельцем сабли являлся состоятельный воин из числа енисейских кыргызов.

\section{ЛИТЕРАТУРА}

Белорыбкин Г.Н. Золоторевское поселение. СПб.; Пенза: Изд-во ПГПУ, 2001. 200 с.

Белорыбкин Г.Н., Гусынин В.А., Измайлов И.Л. Вооружение населения Юго-Западной Булгарии (XXIII века) / Археология Евразийских степей. 2020. № 1. 354c.

Бобров Л. А., Кушкумбаев А.К., Каирмагамбетов А.М., Исмаилов Д. Три сабли монгольского времени с территории Казахстана // Вестник НГУ. Серия: История, филология. 2020. Т. 19, № 7. С. 245-256.

Бобров Л.А., Пронин А.О. Типология казахских сабель XVI - середины XIX в. // Культуры степной Евразии и их взаимодействие с древними цивилизациями. Кн. 2СПб.: ИИМК РАН: Периферия. 2012. C. $572-581$.

Бобров Л. А., Худяков Ю.С. Вооружение и тактика кочевников Центральной Азии и Южной Сибири в эпоху позднего Средневековья и Нового времени (XV - первая половина XVIII в.). СПб. : Фак. филол. и искусств СПбГУ, 2008. 770 с.

Горбунов В.В. Военное дело населения Алтая в III-XIV вв. Ч. II: Наступательное вооружение (оружие). Барнаул: Изд-во Алт. ун-та, 2006. 232 с.

Горелик М.В. Армии монголо-татар X-XIV веков. Воинское искусство, снаряжение, оружие. М.: Восточный горизонт, 2002. $84 \mathrm{c}$.

Горелик М.В. Об одной разновидности евразийских клинков эпохи развитого средневековья // Военное дело народов Сибири и Центральной Азии. Новосибирск: Наука, 2004. С. 86-101.

Горелик М.В. Черкесские воины Золотой Орды (по археологическим данным) // Вестник Института гуманитарных исследований Правительства КБР и КБНЦ РАН. 2008. Вып. 15. С. 158-189.

Горелик M.В., Гредунов Е.В. Группа золотоордынских сабель XIV века из частной коллекции в Украине // Істория зброі. Альманах. 2014. № 10. С. 208-218.

Измайлов И.Л. Вооружение и военное дело населения Волжской Булгарии X - начала ХІІІ в. КазаньМагадан: СВНЦ ДВО РАН, 1997. 212 с.

Измайлов И.Л. Защитники «Стены Искандера». Казань: Татарск. Книжн. Изд-во, 2008. 207 с.

Кочкаров У.Ю. Вооружение воинов Северо-Западного Предкавказья VIII - XIV вв. (оружие ближнего боя). М.: ТАУС, 2008. $176 \mathrm{c.}$

Мясников В.Ю., Ярославцева Л.Г. Три средневековых клинка из коллекции Национального Музея Республики Бурятия // Теория и практика археологических исследований. 2017. №3 (19). С. 57-68.

\footnotetext{
6 На раннем этапе, появление сабель подобного типа в Средней Азии, Китае, Закавказье, и Восточной Европе может быть связано с походами войск Чингиз-хана и его приемников в эти регионы. То есть данные предметы вооружения не были приобретены в ходе торгового обмена, а были утеряны воинами монгольской армии в ходе тех или иных событий.
} 
Обухова М.А. Сабля Монгольского времени из частной коллекции // Археология. Материалы 57-й Международной научной студенческой конференции. (Новосибирск, 14-19 апреля 2019 г.) Новосибирск: Новосибирский национальный исследовательский государственный университет. С. 79-80.

Скобелев С.Г., Рюмшин М.А. Новые материалы по длинноклинковому оружию енисейских кыргызов в развитом и позднем Средневековье // Вестник НГУ. Серия: История, филология. 2010. Т. 9. № 7. C. $144-154$.

Соловьев А.И. Оружие и доспехи. Сибирское вооружение: от каменного века до средневековья. Новосибирск: «ИНФОЛИО-пресс», 2003. 224 с.

Худяков Ю.С. Военное дело кочевников Южной Сибири и Центральной Азии в эпоху развитого средневековья. Новосибирск: Изд-во ИАЭТ СО РАН, 1997. 160 с.

Худяков Ю.С. Вооружение енисейских кыргызов. Новосибирск: Наука, 1980. 176 с.

Худяков Ю.С. Вооружение средневековых кочевников Южной Сибири и Центральной Азии. Новосибирск: Наука, 1986. 269 с.

Ширин Ю.В. Средневековые случайные находки предметов вооружения из Горной Шории // Материалы по военной археологии Алтая и сопредельных территорий / Ред. В.В. Горбунов, А.А. Тишкин. Барнаул: Изд-во Алт. ун-та, 2002. С. 130-134.

Rivkin K., Isaac B. A Study of the Eastern Sword. Printed in Mankato. 2017. 360 p.

The Arts of the Muslim Knight. The Furusiyya Art Foundation Collection. Milan: Skira, 2008. 416 p.

\section{Информация об авторах:}

Бобров Леонид Александрович, доктор исторических наук, ведущий научный сотрудник лаборатории гуманитарных исследований, доцент кафедры археологии и этнографии Новосибирского государственного университета (г. Новосибирск, Россия); spsml@mail.ru

Пронин Алексей Олегович, кандидат исторических наук, директор ГАУК НСО «Исторический парк «Россия - моя история», эксперт Министерства культуры Российской Федерации (г. Новосибирск, Россия); alexey@pronin.asia

Филиппович Юрий Александрович, главный инженер научно-исследовательского проекта «С сибирским воином через века», лаборатория гуманитарных исследований Новосибирского государственного университета; post-ost@yandex.ru

\section{REFERENCES}

Belorybkin, G. N. 2001. Zolotorevskoe poselenie (Zolotorevka Settlement). Saint Petersburg; Penza: Penza State Pedagogical University (in Russian).

Belorybkin, G. N., Gusynin, V. A., Izmailov, I. L. 2020. Vooruzhenie naseleniia yugo-zapadnoi Bulgarii (X - XIII veka) Armament of the Population of South-Western Bolgaria (10th - mid-13th centuries). Arkheologiia Evraziiskikh stepei (Archaeology of Eurasian Steppes) 1 (in Russian).

Bobrov, L. A., Kushkumbaev, A. K., Kairmagambetov, A. M., Islamov, D. 2020. In Vestnik Novosibirskogo Gosudarstvennogo universiteta. Istoriia, filologiya (Bulletin of the Novosibirsk State University: History, Philology) 19 (7), 245-256 (in Russian).

Bobrov, L. A., Khudyakov, Yu. S. 2008. Vooruzhenie i taktika kochevnikov Tsentral'noy Azii i Yuzhnoy Sibiri $v$ epokhu pozdnego srednevekov'ya i rannego Novogo vremeni (XV-pervaya polovina XVIII v.). (Armament and Tactics of the Central Asian and South Siberian Nomads in the Late Middle Ages and the Early Modern Time (15th - first half of 18th cc.). Saint Petersburg: Faculty of Filology, Saint Petersburg State University (in Russian).

Bobrov, L. A., Pronin, A. O. 2012. In Kul'tury stepnoi Evrazii i ikh vzaimodeistvie s drevnimi tsivilizatsiiami (Cultures of Steppe Eurasia and Their Interactions with Ancient Civilizations) 2. Saint Peterburg: Institute for the History of Material Culture, Russian Academy of Sciences; "Periferiia" Publ., 572-581 (in Russian).

Gorbunov, V. V. 2006. Voennoe delo naseleniya Altaya v III-XIV vv. Chast' I: Nastupatel'noe vooruzhenie (oruzhie) (Military Science of Altay Population in III-XIV Centuries. Part II. Offensive Armament (Weapons)). Barnaul: Altay State University (in Russian).

Gorelik, M. V. 2002. Armii mongolo-tatar X-XIVvekov. Voinskoe iskusstvo, snaryazhenie, oruzhie (Armies of the Mongol-Tatars in the 10th-14th cc. Military Arts, Equipment and Armament). Moscow: "Vostochniy gorizont" Publ. (in Russian).

Gorelik, M. V. 2004. In Voennoe delo narodov Sibiri i Tsentralnoi Azii (Military Art of the Peoples of Siberia and Central Asia). Novosibirsk: "Nauka" Publ., 86-101 (in Russian). 
Gorelik, M. V. 2008. In Vestnik Instituta gumanitarnykh issledovanii Pravitel'stva KBR i KBNC RAN (Bulletin of the Kabardian-Balkarian Institute for the Humanities Research). 15, 158-189 (in Russian).

Gorelik, M. V., Gredunov, E. V. 2014 In Istoriia zbroi. Almanakh (History of weapons. The almanac) 10, C. 208-218 (in Russian).

Izmailov, I. L. 1997. Vooruzhenie i voennoe delo naseleniya Volzhskoy Bulgarii X - nachala XIII v. (Armament and Warfare of the population of Volga Bulgaria 10th-beginning of 13th century) Kazan-Magadan: North-East Scientific Center, Russia Academy of Sciences Far East Branch (in Russian).

Izmailov, I. L. 2008. Zashchitniki "Steny Iskandera" (Defenders of the Iskander Wall). Kazan: "Tatarskoe knizhnoe izdatel'stvo" Publ. (in Russian)..

Kochkarov, U. Yu. 2008. Vooruzhenie voinov Severo-Zapadnogo Predkavkaziia VIII - XIV vv. (oruzhie blizhnego boja) The arm of the Norht-West Ciscaucasia warriors in VIII-XIV (close-in fighting weapons). Moscow: "Taus" Publ. (in Russian).

Myasnikov, V. Yu., Yaroslavskaya, L. G. 2017. In Teoriia i praktika arheologicheskikh issledovaniy (Theory and practice of archaeological research) 19(3), 57-68 (in Russian).

Obukhova, M. A. 2019. In Arkheologiia (Archaeology). Novosibirsk Novosibirsk State University, 79-80 (in Russian).

Skobelev, S. G., Ryumin, M. A. 2010. In Vestnik Novosibirskogo Gosudarstvennogo universiteta. Istoriia, filologiya (Bulletin of the Novosibirsk State University: History, Philology) 9 (7), 144-154 (in Russian).

Solov'ev, A. I. 2003. Oruzhie I dospekhi. Sibirskoe vooruzhenie: ot kamennogo veka do srednevekov'ia (Weapons and Armor. Siberian Armament: from the stone age to the middle ages). Novosibirsk: INFOLIOpress" Publ. (in Russian).

Khudyakov, Yu. S. 1980. Vooruzhenie eniseiskikh kyrgyzov (Armament of the Yenisei Kyrgyz). Novosibirsk: "Nauka" Publ. (in Russian).

Khudiakov, Yu. S. 1986. Vooruzhenie srednevekovykh kochevnikov Iuzhnoi Sibiri i Tsentral'noi Azii (Arms of the Medieval Nomads of the Sourthern Siberia and Central Asia). Novosibirsk: "Nauka" Publ. (in Russian).

Khudyakov, Yu. S. 1997. Voennoe delo kochevnikov Yuzhoi Sibiri I Tsentral'noi Azii v epokhu razvitovogo srednevekov'ia (Military Art of the Nomads of South Siberia and Central Asia in the Developed Middle Ages). Novosibirsk: Siberian Branch of the Russian Academy of Sciences, Institute for Archaeology and Ethnography (in Russian).

Shirin, Yu. V. 2002. In Gorbunov, V. V., Tishkin, A. A. (eds.). Materialy po voennoi arkheologii Altaia $i$ sopredel'nykh territorii (Materials on the Military Archaeology of the Altai and the Neighbouring Territories). Barnaul: Altai State University Publ., 130-134 (in Russian).

Rivkin, K., Isaac, B. 2017. A Study of the Eastern Sword. Printed in Mankato.

2008. The Arts of the Muslim Knight. The Furusiyya Art Foundation Collection. Milan: Skira.

\section{About the Authors:}

Bobrov Leonid A., Doctor of Historical Sciences, Associate Professor, Novosibirsk State University, Pirogov Str. 1, Novosibirsk, 630090, Russian Federation; spsml@mail.ru

Pronin Alexey O., Candidate of Historical Sciences, State autonomous institution of Novosibirsk region «Historical park «Russia - my history», expert of the Ministry of Culture of the Russian Federation, Vasilya Staroschuka str., 24, Novosibirsk, 630017, Russian Federation; alexey@pronin.asia

Filippovitch Yuriy A., Chief Engineer of the research project "With the Siberian Warrior Through the Centuries", Laboratory for Humanities Studies, Novosibirsk State University, 1 Pirogov Str., Novosibirsk, 630090, Russian Federation; post-ost@yandex.ru

Статья поступила в журнал 01.08.2020 г. Статья принята к публикации 01.09.2020 г. Авторы внесли равноценный вклад в работу. 

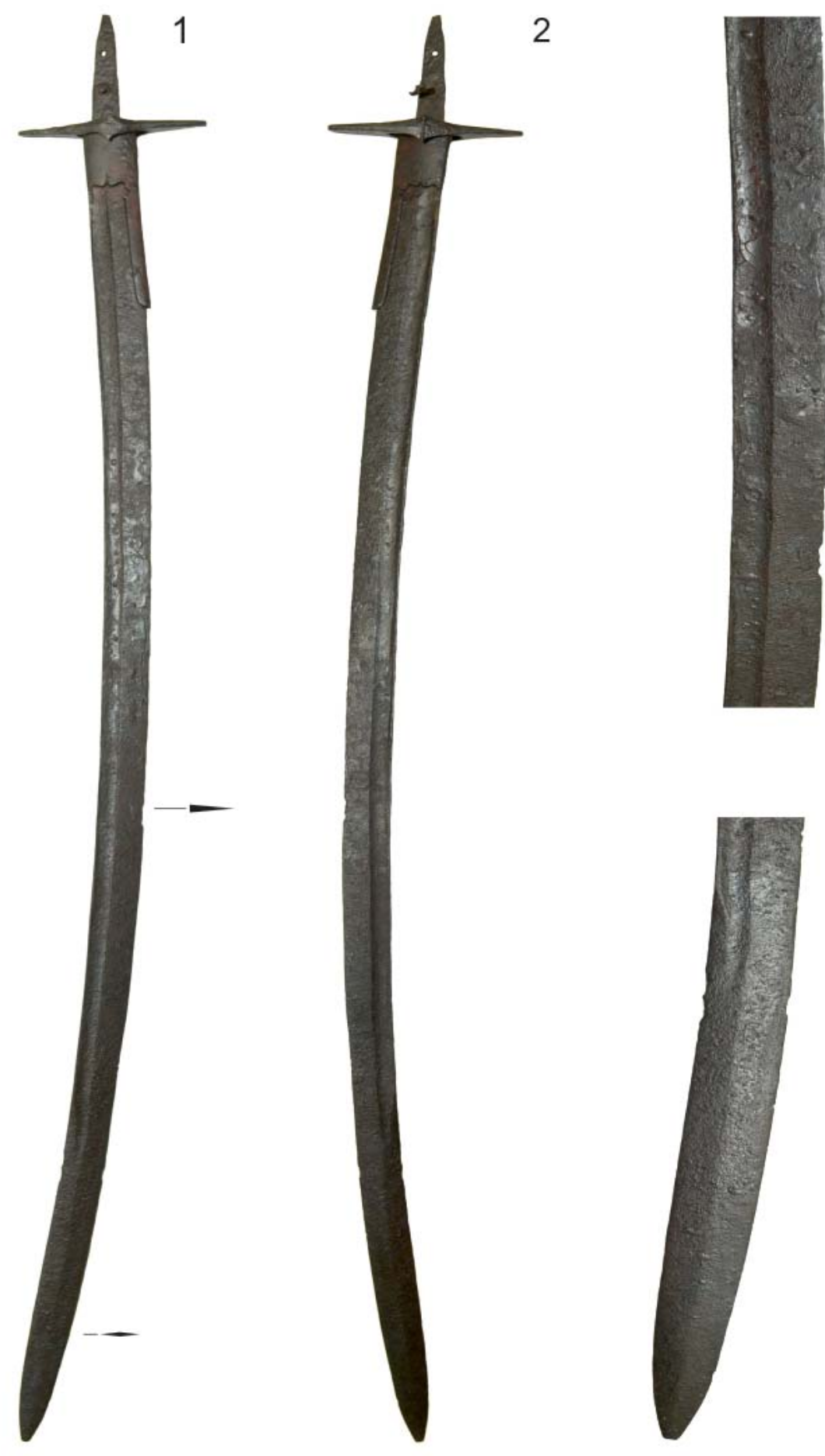

4

Рис. 1. (фото). Сабля из Минусинской котловины: 1,2 - общий вид; 3 - фрагмент клинка с долом; 4 - острие (фото А.О. Пронина; без масштаба)

Fig. 1. (photo). Saber from Minusinsk Hollow: 1,2 - general view; 3 - fragment of a blade with a fuller; 4 - tip (photo by A.O. Pronin; not to scale) 


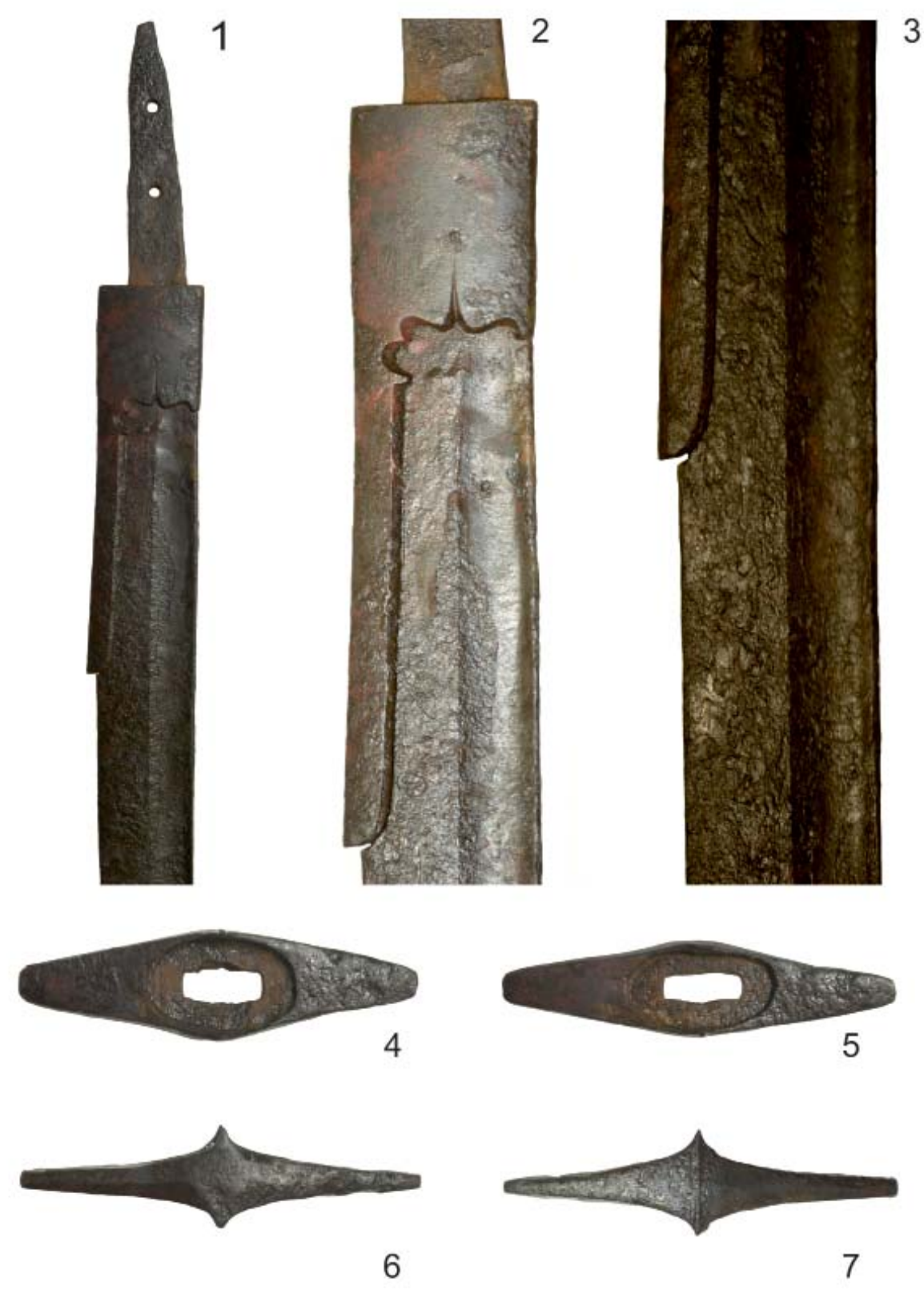

Рис. 2 (фото). Сабля из Минусинской котловины: 1 - фрагмент верхней части сабельной полосы с хвостовиком и обоймицей с «язычком»; 2 - обоймица с «язычком»; 3 - фрагмент «язычка» и клинка с долом; 4, 5 - гарда, вид сверху и снизу; 6, 7 - гарда, вид сбоку (фото А.О. Пронина; без масштаба).

Fig. 2 (photo). Saber from Minusinsk Hollow: 1 - fragment of the upper portion of a saber strip with a shank and ferrule with a "tongue"; 2 - ferrule with a "tongue"; 3 - fragment of a "tongue" and blade with a fuller; 4, 5-guard, top and bottom views; 6, 7 - guard, side view (photos by A.O. Pronin; not to scale) 
САБЛЯ МОНГОЛЬСКОГО ВРЕМЕНИ ИЗ МИНУСИНСКОЙ КОТЛОВИНЫ

363
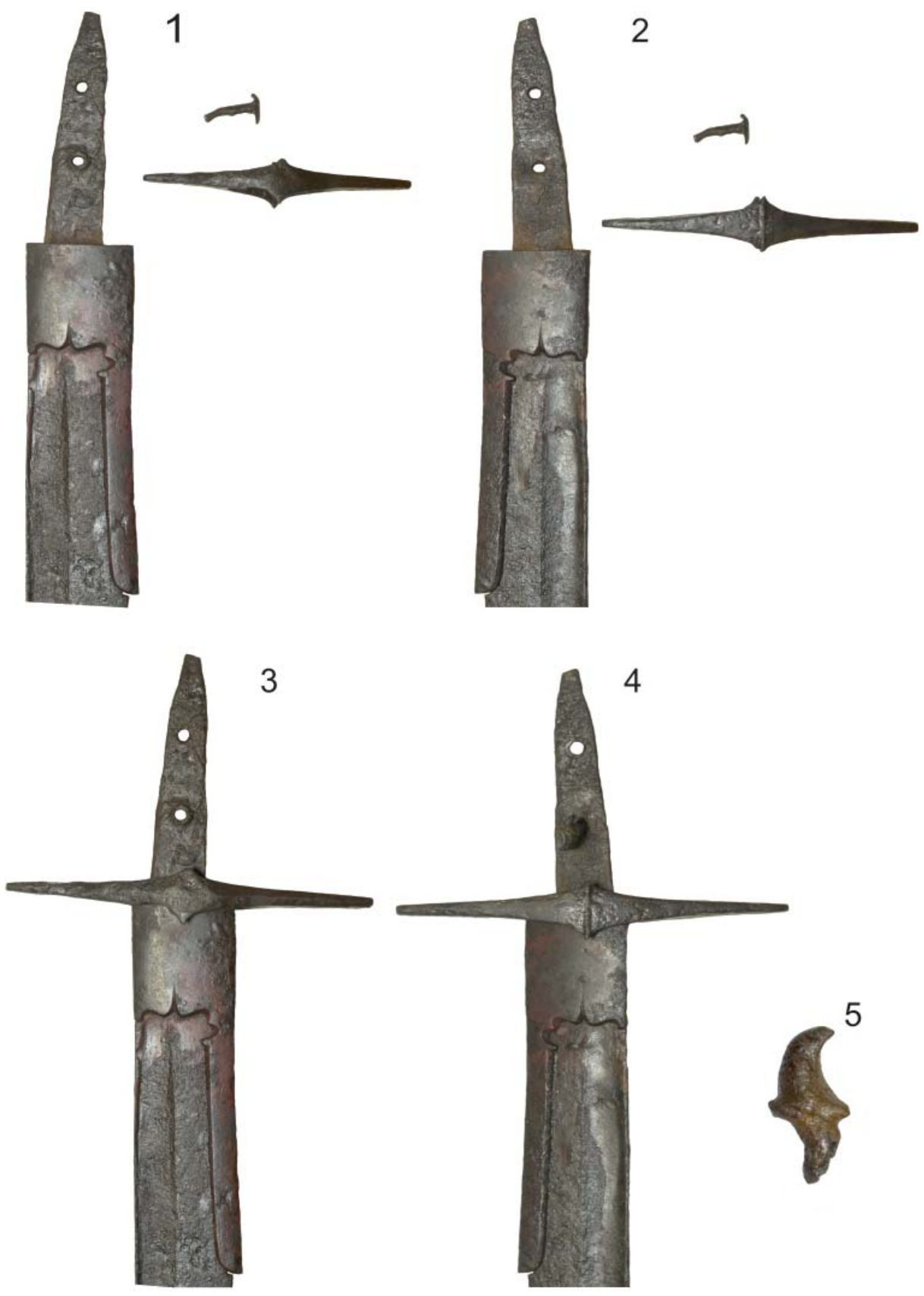

Рис. 3 (фото). Сабля из Минусинской котловины: 1, 2 - фрагмент верхней части сабельной полосы с хвостовиком, обоймицей с «язычком», снятой гардой и вынутой заклепкой; 3, 4 - верхняя часть сабли; 5 - шляпка заклепки (фото А.О. Пронина; без масштаба).

Fig. 3 (photo). Saber from Minusinsk Hollow: 1, 2 - fragment of the upper portion of a saber strip with a shank, a ferrule with a "tongue", withdrawn guard and removed rivet; 3, 4- upper portion of the saber; 5 - rivet head (photos by A.O. Pronin; not to scale) 

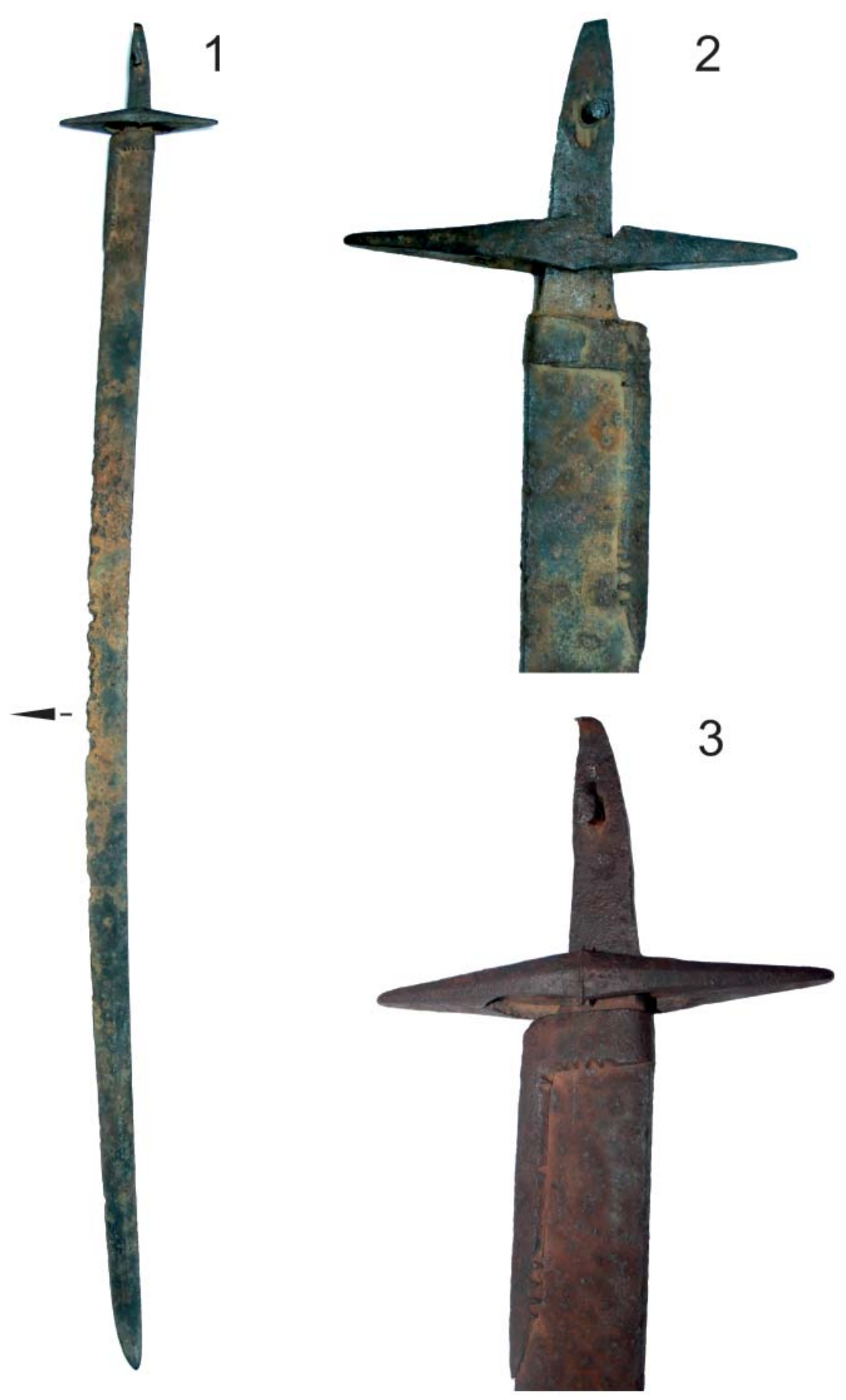

Рис. 4 (фото). Сабля из числа случайных находок районе г. Щучинска Акмолинской области Республики Казахстан: 1 - общий вид; 2, 3 - эфес (фото Д. Каусылова; без масштаба) (по: Бобров и др. 2020)

Fig. 4 (photo). Saber from the series of accidental finds in the area of Shchuchinsk, Akmola Region of the Republic of Kazakhstan: 1 - general view; 2, 3 - handle (photos by D. Kausylov; not to scale) (after: Bobrov et al. 2020) 

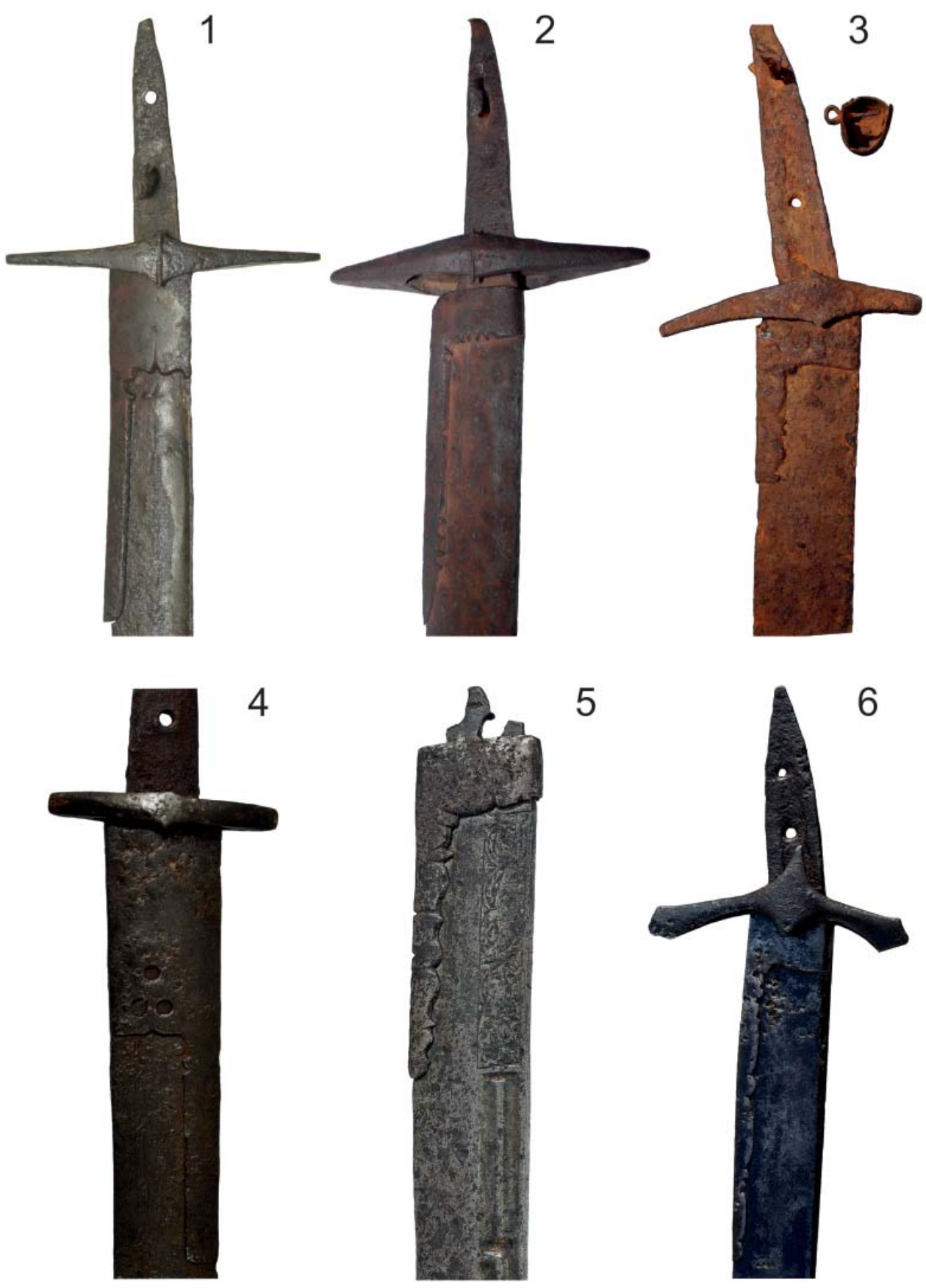

Рис. 5 (фото). Эфесы и фрагменты клинков сабель XIII-XIV вв.: 1 - из Минусинской котловины; 2 - из Северного Казахстана; 3, 4, 6 - из Восточной Европы; 5 - из Ирана. 1-4, 6 - частные коллекции, 5 - Фонд искусств Фурусия (2 - по: Бобров и др., 2020; 3-6 - по: Rivkin, Isaac, 2017; без масштаба).

Fig. 5 (photo). Handles and fragments of saber blades of the 13th-14th centuries: 1 - from Minusinsk Hollow; 2 - from Northern Kazakhstan; 3, 4, 6 - from Eastern Europe; 5 - from Iran. 1-4, 6 - private collections, 5 - Furusia Art Foundation (2 - after: Bobrov et al., 2020; 3-6 - after: Rivkin, Isaac, 2017; not to scale) 